\title{
Clinical Reasoning: A 14-year-old boy with acute weakness, paresthesias, and headache
}

Ronald R. Seese, MD, PhD, Daniel Guillen, MD, Jenna M. Gaesser, MD, and Hoda Z. Abdel-Hamid, MD

Neurology ${ }^{\circledR}$ 2020;95:e1285-e1289. doi:10.1212/WNL.0000000000010088
Correspondence

Dr. Seese

ronald.seese@chp.edu

\section{Section 1}

A 14-year-old boy with a history of atrial tachycardia presented to the emergency department with acute right foot weakness. One month prior to presentation, he had a self-resolving diarrheal illness and bacterial pneumonia treated with antibiotics. Two weeks later, he endorsed a dull headache, increased irritability, and neck pain. One week prior to presentation, he developed intermittent urinary retention and episodes of flushing and redness of his right face. He fell 5 days prior to presentation and in the ensuing days, he complained of bilateral hip pain and paresthesias that progressively spread to involve bilateral thighs. On the day of presentation, the patient noticed weakness of his right ankle and foot. There was no history of fever. He denied joint pain, swelling, rash, or facial droop, but he did endorse mild sound sensitivity.

The patient's neurologic examination on presentation consisted of normal mental status and cranial nerve function. Brudzinski and Kernig signs were negative. Muscle tone and bulk were normal. Power in all groups was normal except in the right ankle, where dorsiflexion, inversion, and eversion were decreased (4/5). Pinprick sensation was somewhat diminished on the right leg and joint position was normal. There was decreased vibratory sensation at the right ankle. Reflexes were normal $(2+)$ in the upper extremities but absent $(0)$ in the Achilles reflex bilaterally and diminished $(1+)$ in the patella bilaterally. Coordination was normal. Gait was notable for right foot drop.

\section{Questions for consideration:}

1. How would you summarize and localize this patient's symptoms?

2. What is the differential diagnosis in this case?

GO TO SECTION 2 


\section{Section 2}

This adolescent boy presented with acute right lower extremity weakness and subacute headache, irritability, paresthesias, diaphoresis, and urinary retention following recent gastrointestinal and respiratory infections. His examination at presentation was notable for right foot drop, hyporeflexia, and diminished vibratory sensation, but his mental status and cranial nerve function were normal. While acute weakness and areflexia localize to the lower motor neuron, paresthesias suggest involvement of the dorsal roots. Urinary retention and diaphoresis implicate the autonomic nervous system and the spinal cord. Although nonspecific, headache, phonophobia, and irritability may be part of meningitis.

A single lesion is unlikely to explain these findings of polyneuropathy and myelitis. The differential diagnosis of acute weakness and areflexia includes trauma (e.g., spinal shock, acute nerve injury), a parainfectious process (e.g., acute inflammatory demyelinating polyradiculoneuropathy [AIDP]), and a direct infectious process (e.g., poliovirus, West Nile virus, acute flaccid myelitis $[\mathrm{AFM}])$. AIDP involves progressive, often ascending, demyelination of the peripheral nerves that involves both motor and sensory fibers. CSF analysis is crucial in the diagnosis of AIDP, as protein levels are elevated and white blood cell counts are normal. AFM is limited to the alpha motor neuron originating from the ventral horn of the spinal cord. Thus, by definition, AFM does not present with sensory changes. Myelitis of the sacral cord often includes urinary retention because of involvement of parasympathetic neurons arising from the lateral horn. If the spinal cord's ascending sensory tracts are involved, a "sensory level" can be appreciated. No sensory level was present in our patient. Demyelination not related to infection is also a possibility, such as in neuromyelitis optica (NMO), which is tested for with a specific serum autoantibody. Finally, in endemic areas, early disseminated Lyme disease may cause a polyradiculitis or myelitis.

\section{Question for consideration:}

1. What diagnostic workup can be employed to narrow the differential diagnosis?

GO TO SECTION 3 


\section{Section 3}

Neuroimaging and CSF analysis are crucial to help narrow the differential diagnosis. Leptomeningeal enhancement can be seen in meningitis. T2 hyperintensities of the spinal cord are suggestive of myelitis and the edema is limited to the ventral horn in AFM. Enhancement of the cauda equina rootlets, on the other hand, is a radiologic hallmark suggestive of AIDP. CSF pleocytosis is often seen in direct infectious processes, while cytoalbuminergic dissociation (elevated protein with no pleocytosis) is appreciated in AIDP. Other tests to consider include serum Lyme and NMO aquaporin-4 titers.

Brain MRI in this patient showed a nonenhancing T2hyperintense lesion of the left parietal subcortical white matter (figure, A) as well as thickening and enhancement of the right trigeminal nerve (figure, B). Spine MRI demonstrated diffuse increased T2-weighted signal of the spinal cord from $\mathrm{T} 11$ to the conus medullaris (figure, $\mathrm{C}$ and $\mathrm{D}$ ) as well as thickening and enhancement of multiple cauda equina rootlets (figure, E). CSF analysis was consistent with a bacterial meningitis: the white blood cell count was elevated (973 cells per $\mu \mathrm{L}, 84 \%$ of which were lymphocytes) in the setting of normal red blood cell count ( 15 cells per $\mu \mathrm{L}$ ), while glucose was decreased $(33 \mathrm{mg} / \mathrm{dL})$ and protein was increased $(178$ $\mathrm{mg} / \mathrm{dL}$ ). CSF culture and gram stain were negative. Twotiered serum testing for Lyme disease was unquestionably positive: ELISA for immunoglobulin $\mathrm{M}$ (IgM) was positive and Western blot IgM bands at $23 \mathrm{kDa}, 39 \mathrm{kDa}$, and $41 \mathrm{kDa}$ were reactive. Additional workup included normal CSF immunoglobulin G index, 1 CSF oligoclonal band, and absent serum autoantibodies for antinuclear antibody, myelin oligodendrocyte glycoprotein, or aquaporin 4 .

Positive 2-tiered serum testing for Lyme disease combined with lymphocytic pleocytosis in the CSF and MRI evidence of cranial neuritis, radiculoneuritis, and myelitis confirmed the diagnosis of early disseminated Lyme neuroborreliosis.
Figure Neuroimaging findings in a 14-year-old boy with multiple clinical features of neuroborreliosis
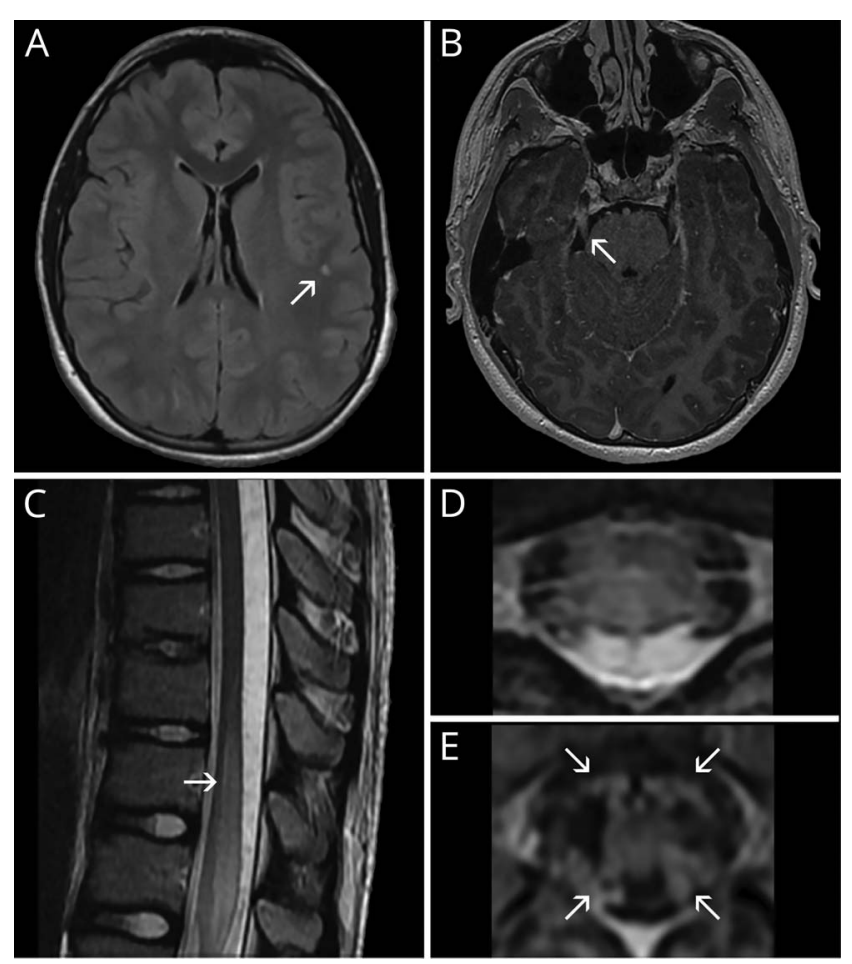

(A) T2-weighted axial fluid-attenuated inversion recovery imaging demonstrates a left parietal subcortical lesion (arrow). In postcontrast imaging (not shown), this lesion does not enhance. (B) Contrast-enhanced T2-weighted axial imaging shows thickening and enhancement of the right trigeminal nerve (CN V; arrow). (C) Unenhanced sagittal T2-weighted imaging of the spinal cord shows diffuse increased signal (arrow) spanning from T11 to the conus medullaris. (D) Axial imaging of spinal cord demonstrates patchy increased T2-weighted signaling of the gray matter and overall cord edema. (E) Gadolinium-enhanced axial T2-weighted imaging of the cauda equina shows enhancement of multiple rootlets (arrows).

\section{Question for consideration:}

1. What are the next steps in management?

\section{GO TO SECTION 4}




\section{Section 4}

Negative inspiratory force and vital capacity are important to obtain immediately in a patient with acute weakness and areflexia. These measures were normal in our patient. Although a complete neurodiagnostic workup undoubtedly assists with medical management, a significant delay in obtaining neuroaxis MRI and CSF often occurs in pediatric patients who require sedation. While awaiting workup, our patient received IV immunoglobulin (IVIg; $2 \mathrm{~g} / \mathrm{Kg}$ over 5 days) for presumed AIDP. Twelve hours into his hospitalization, he developed right facial weakness involving the forehead that resolved within 48 hours. Once the Lyme ELISA results returned positive, IV ceftriaxone was initiated. Imaging was then completed and demonstrated cranial nerve V and VII enhancement, segmental myelitis, and radiculoneuritis. Methylprednisolone was deferred given that steroids can worsen facial palsy associated with Lyme disease $^{1}$ and because IV antibiotics improved the patient's strength and resolved his urinary retention. The IVIg course was completed after the workup confirmed a diagnosis of neuroborreliosis, because IVIg has been reported to help with symptoms of early disseminated Lyme disease when clinical features of AIDP are also present. ${ }^{2}$ The patient was discharged home with a 21-day course of doxycycline. On follow-up 1 month after discharge, his neurologic examination was markedly improved: right dorsiflexion was $5-/ 5$, patellar reflexes were now present at $2+$, and his Achilles reflexes were obtained (left: $2+$, right $1+$ ). Paresthesias had resolved completely. He was able to resume all his normal activities.

\section{Discussion}

Diagnosis of neuroborreliosis is based on nervous system involvement with positive serologic testing in an endemic area. A history of erythema migrans may or may not be present. In a large study of patients with suspected neuroborreliosis, serum antibodies were present in $97 \%$ of cases. CSF antibodies were present in only 1 of the 4 remaining cases, in which serologies were negative. ${ }^{3}$ Thus, serologic 2-tiered testing (ELISA followed by Western blotting) is often used clinically. Lumbar puncture can be of use to confirm elevated opening pressure in patients with optic disc edema and thus suspected idiopathic intracranial hypertension. Ceftriaxone or doxycycline are IV and enteral antimicrobials for neuroborreliosis, respectively. Acetazolamide can be used in Lyme-associated idiopathic intracranial hypertension. ${ }^{4}$

Many distinct nervous system manifestations can follow Borrelia burgdorferi infection. Meningitis, cranial neuropathies, radiculoneuritis, and encephalomyelitis are all considered early disseminated manifestations, occurring weeks to months after infection. Polyneuropathies, on the other hand, are late disseminated symptoms, with onset many months after an infection. ${ }^{5}$ In endemic areas, meningitis, cranial neuropathy, and radiculoneuritis are the most commonly reported nervous system complications of Lyme disease. Based on EMG and nerve conduction studies, ${ }^{6}$ the pathophysiology of peripheral nervous system (PNS) involvement in Lyme disease is suspected to involve multifocal axonal injury.

Segmental myelitis secondary to Lyme disease occurs in fewer than $5 \%$ of cases. ${ }^{5,7}$ To our knowledge, this is only the seventh report of a child with myelitis secondary to Lyme disease ${ }^{8}$ and the first of myelitis associated with meningitis and radiculoneuritis. Whereas the pathophysiology is less understood than that for PNS involvement, human pathologic studies have demonstrated plasma cell and lymphocyte infiltrate within the spinal cord white matter. ${ }^{9}$ Using infected rhesus macaques, Bai et al. ${ }^{10}$ demonstrated Borrelia spirochetes within the cord meninges, dorsal root ganglia, and motor and sensory spinal roots. However, spirochetes were not observed in the spinal cord parenchyma itself.

In the patient described above, early confirmation of Lyme disease allowed for timely initiation of antimicrobials. Particularly in endemic areas, neuroborreliosis should be strongly considered in both adult and pediatric patients with neurologic symptoms that do not localize to a single lesion. The spectrum of neurologic findings in early disseminated Lyme disease often consists of meningitis, cranial neuropathy, or radiculoneuritis. Encephalitis or myelitis can also rarely occur.

\section{Study funding}

No targeted funding reported.

\section{Disclosure}

R.R. Seese, D. Guillen, and J.M. Gaesser report no disclosures relevant to the manuscript. H.Z. Abdel-Hamid serves on the scientific advisory board and acts as a consultant for Sarepta Therapeutics, Biogen, and Avexis. Go to Neurology.org/N for full disclosures.

\begin{tabular}{lll} 
Appendix & Authors & \\
\hline Name & Location & Contribution \\
\hline $\begin{array}{l}\text { Ronald } \\
\text { Seese, MD, } \\
\text { PhD }\end{array}$ & $\begin{array}{l}\text { UPMC Children's } \\
\text { Hospital of } \\
\text { Pittsburgh }\end{array}$ & $\begin{array}{l}\text { Designed and conceptualized } \\
\text { study, analyzed and interpreted the } \\
\text { data, drafted and revised the } \\
\text { manuscript for intellectual content }\end{array}$ \\
\hline $\begin{array}{l}\text { Daniel } \\
\text { Guillen, MD }\end{array}$ & $\begin{array}{l}\text { UPMC Children's } \\
\text { Hospital of } \\
\text { Pittsburgh }\end{array}$ & $\begin{array}{l}\text { Interpreted the data, revised the } \\
\text { manuscript for intellectual content }\end{array}$ \\
\hline $\begin{array}{l}\text { Jenna } \\
\text { Gaesser, } \\
\text { MD }\end{array}$ & $\begin{array}{l}\text { UPMC Children's } \\
\text { Hospital of }\end{array}$ & $\begin{array}{l}\text { Interpreted the data, revised the } \\
\text { manuscript for intellectual content }\end{array}$ \\
\hline $\begin{array}{l}\text { Podtsburgh } \\
\text { Abdel- } \\
\text { Hamid, MD }\end{array}$ & $\begin{array}{l}\text { UPMC Children's } \\
\text { Hospital of }\end{array}$ & $\begin{array}{l}\text { Interpreted the data, revised the } \\
\text { manuscript for intellectual content }\end{array}$ \\
\hline
\end{tabular}




\section{References}

1. Jowett N, Gaudin RA, Banks CA, Hadlock TA. Steroid use in Lyme disease-associated facial palsy is associated with worse long-term outcomes. Laryngoscope 2017;127: 1451-1458.

2. Patel K, Shah S, Subedi D. Clinical association: Lyme disease and Guillain-Barre syndrome. Am J Emerg Med 2017;35:e1581-e1582.

3. Ogrinc K, Lusa L, Lotric-Furlan S, et al. Course and outcome of early European Lyme neuroborreliosis (Bannwarth syndrome): clinical and laboratory findings. Clin Infect Dis 2016;63:346-353.

4. Wormser GP, Dattwyler RJ, Shapiro ED, et al. The clinical assessment, treatment, and prevention of Lyme disease, human granulocytic anaplasmosis, and babesiosis: clinical practice guidelines by the Infectious Diseases Society of America. Clin Infect Dis 2006;43:1089-1134.
5. Koedel U, Fingerle V, Pfister HW. Lyme neuroborreliosis: epidemiology, diagnosis and management. Nat Rev Neurol 2015;11:446-456.

6. Halperin J, Luft BJ, Volkman DJ, Dattwyler RJ. Lyme neuroborreliosis: peripheral nervous system manifestations. Brain 1990;113:1207-1221.

7. Dumic I, Vitorovic D, Spritzer S, Sviggum E, Patel J, Ramanan P. Acute transverse myelitis: a rare clinical manifestation of Lyme neuroborreliosis. IDCases 2019;15:e00479.

8. Erol I, Kilicarslan B, Saygi S, Demir S, Alehan F. Acute transverse myelitis in a child with Lyme disease and a review of literature. Pediatr Neurol 2013;48:325-328.

9. Bourque M, Morissette M, Di Paolo T. Neuroprotection in Parkinsonian-treated mice via estrogen receptor alpha activation requires $\mathrm{G}$ protein-coupled estrogen receptor 1. Neuropharmacology 2015;95:343-352.

10. Bai Y, Narayan K, Dail D, et al. Spinal cord involvement in the nonhuman primate model of Lyme disease. Lab Invest 2004;84:160-172. 


\section{Neurology}

Clinical Reasoning: A 14-year-old boy with acute weakness, paresthesias, and headache Ronald R. Seese, Daniel Guillen, Jenna M. Gaesser, et al.

Neurology 2020;95;e1285-e1289 Published Online before print July 29, 2020

DOI 10.1212/WNL.0000000000010088

This information is current as of July 29, 2020

\section{Updated Information \&} Services

References

Subspecialty Collections

\section{Permissions \& Licensing}

Reprints including high resolution figures, can be found at: http://n.neurology.org/content/95/9/e1285.full

This article cites 10 articles, 0 of which you can access for free at: http://n.neurology.org/content/95/9/e1285.full\#ref-list-1

This article, along with others on similar topics, appears in the following collection(s):

All Pediatric

http://n.neurology.org/cgi/collection/all_pediatric

Bacterial infections

http://n.neurology.org/cgi/collection/bacterial_infections

Cranial neuropathy

http://n.neurology.org/cgi/collection/cranial_neuropathy

Peripheral neuropathy

http://n.neurology.org/cgi/collection/peripheral_neuropathy

Transverse myelitis

http://n.neurology.org/cgi/collection/transverse_myelitis

Information about reproducing this article in parts (figures,tables) or in its entirety can be found online at:

http://www.neurology.org/about/about_the_journal\#permissions

Information about ordering reprints can be found online:

http://n.neurology.org/subscribers/advertise

Neurology ${ }^{\circledR}$ is the official journal of the American Academy of Neurology. Published continuously since 1951, it is now a weekly with 48 issues per year. Copyright (C) 2020 American Academy of Neurology. All rights reserved. Print ISSN: 0028-3878. Online ISSN: 1526-632X.

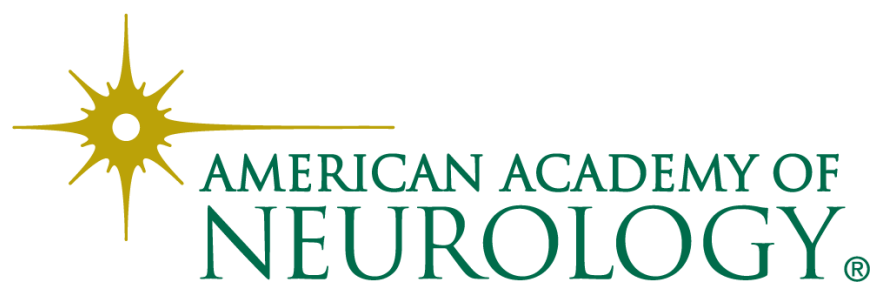

